ORIGINAL ARTICLE

\title{
Factors influencing the difference between maternal and cord blood lead
}

\author{
E W Harville, I Hertz-Picciotto, M Schramm, M Watt-Morse, K Chantala, J Osterloh, P J Parsons, \\ W Rogan
}

Occup Environ Med 2005;62:263-269. doi: 10.1136/oem.2003.012492

\begin{abstract}
See end of article for authors' affiliations

......................

Correspondence to: Dr E W Harville, CB \#7435, Department of Epidemiology, University of North Carolina-Chapel Hill, Chapel Hill, NC 27599-7435, USA; ewh@unc.edu
\end{abstract}

Accepted 1 December 2004

\begin{abstract}
Aims: To determine the factors that affect why some infants receive higher exposures relative to the mother's body burden than do others.

Methods: A total of 159 mother-infant pairs from a cohort of women receiving prenatal care at MageeWomens Hospital in Pittsburgh, PA from 1992 to 1995 provided blood samples at delivery for lead determination. The difference between cord and maternal blood lead concentration $(\mathrm{PbB})$ and a dichotomous variable indicator of higher cord than maternal $\mathrm{PbB}$, were examined as indicators of relative transfer. Women were interviewed twice during the pregnancy about lifestyle, medical history, calcium nutrition, and physical activity.

Results: Higher blood pressure was associated with relatively greater cord compared with maternal PbB, as was maternal alcohol use. Sickle cell trait and higher haemoglobin were associated with a lower cord relative to maternal blood lead $\mathrm{PbB}$. No association was seen with smoking, physical exertion, or calcium consumption.

Conclusion: While reduction in maternal exposure will reduce fetal exposure, it may also be possible to mitigate infant lead exposure by reducing transfer from the pregnant woman. Interventions aimed at reducing blood pressure and alcohol consumption during pregnancy may be useful in this regard.
\end{abstract}

$E$ xposure to lead causes developmental problems. Although postnatal and childhood exposure can have effects at low concentrations, ${ }^{1}$ children who have been exposed to lead in utero may also suffer from deficits in development (such as intelligence, information processing, memory, and verbal skills), ${ }^{2-7}$ growth, ${ }^{89}$ and behaviour. ${ }^{10}{ }^{11}$ Because lead is incorporated into the bone matrix where it is retained for decades, ${ }^{12} 13$ prenatal exposure to lead also contributes to an earlier and cumulatively greater body burden. ${ }^{14}{ }^{15}$

Maternal and infant blood lead levels $(\mathrm{PbB})$ are highly correlated across a wide range of exposure levels, ${ }^{16-18}$ so the most obvious sources of variation in fetal lead dose are those that affect the maternal $\mathrm{PbB}$. Some sources of infant $\mathrm{PbB}$ reflect direct maternal exposure, such as occupational lead exposure, exposure to lead paint, or use of lead glazed ceramics. ${ }^{19}$ Since cigarette smoke contains lead, ${ }^{20}{ }^{21}$ smoking and passive smoking could fall into this category as well. ${ }^{22}$ Other factors associated with infant $\mathrm{PbB}$ may reflect a lifestyle associated with increased environmental exposure to lead. Maternal coffee consumption and alcohol use, ${ }^{22}{ }^{23}$ higher blood pressure, ${ }^{24} 25$ and seasonal patterns ${ }^{26-28}$ are such variables.

For over 30 years, it has been recognised that lead freely crosses the placenta via diffusion. ${ }^{29}{ }^{30}$ It has generally been assumed that there is no general enhancement or barrier to transfer. $^{31}$ However, factors besides the maternal lead exposure and $\mathrm{PbB}$ also appear to affect the concentration in fetal blood. Although maternal $\mathrm{PbB}$ is on average about $30 \%$ higher than the infant's, in most studies approximately one quarter of the infants have $\mathrm{PbB}$ higher than their mothers. ${ }^{32-36}$ Rothenberg and coworkers reported that drinking milk rarely, higher maternal age and parity, and caesarean section delivery predicted increased cord lead after controlling for maternal PbB. ${ }^{37}{ }^{38}$ Sikorski et al found higher maternal-fetal ratios in rural subjects, and a correlation between maternal: fetal lead ratio and maternal:fetal iron and zinc ratios. ${ }^{39}$
Given inter-individual variability in maternal:cord $\mathrm{PbB}$, we hypothesised that there might be modifiable factors that contribute to passage of lead to the fetus and that identification of such factors could suggest ways to reduce the burden of lead in newborns beyond what is achieved by reducing maternal lead exposure. For this reason, we examined variables that might influence the amount of lead that an infant receives during gestation relative to maternal burden.

\section{MATERIALS AND METHODS \\ Subjects}

During 1992-95, women were recruited for a longitudinal study of lead, calcium, and blood pressure during pregnancy. ${ }^{40}$ Women were eligible to participate if they were in prenatal care before week 12, planned to deliver at MageeWomens Hospital, had single gestations, spoke English, were over 18, were white or African-American, and did not have chronic diseases. A total of 498 women were part of the initial cohort; 24 delivered elsewhere and 44 miscarried. Whole blood samples were collected from the women at up to five points during pregnancy and at delivery. Because of budget constraints, it was only possible to assay one sample per trimester for some women: 345 had at least one lead measurement taken, and of these, 229 had PbB determination on their blood sample collected at delivery. A total of 162 infants had cord blood lead determined, leading to 159 pairs with lead measurements available for this analysis (fig 1).

Protocols used in this study were approved by the Institutional Review Boards of Magee-Womens Hospital and the University of North Carolina School of Public

Abbreviations: AAS, atomic absorption spectroscopy; ALA-D, $\delta$ aminolevulinic acid dehydratase; BMI, body mass index; CLIA, Clinical Laboratory Improvement Amendment of 1988; $\mathrm{Hb}$, haemoglobin; $\mathrm{PbB}$, blood lead concentration; RBC, red blood cell 


\section{Main messages}

- Higher blood pressure in some groups and alcohol consumption were associated with more lead in cord blood relative to maternal blood lead.

- Higher haemoglobin and sickle cell trait were associated with reduced lead in cord blood relative to maternal blood lead.

- No associations were seen with calcium intake, physical activity, or smoking.

Health. Written informed consent was obtained from all subjects.

\section{Lead determination}

The protocol for blood drawing and lead measurement has been previously described..$^{40}$ The University of California San Francisco-San Francisco General Hospital Metals Laboratory analysed samples concurrently with the study data collection, using electrothermal atomic absorption spectroscopy (AAS) with continuum background correction. Interassay precision had a coefficient of variation of $6 \%$ at $2 \mu \mathrm{g} / \mathrm{dl}$. In 1998 the Lead Poisoning/Trace Elements Laboratory at the New York State Department of Health analysed blood samples that had been frozen, using electrothermal atomisation AAS with Zeeman background correction. ${ }^{41}$ This method is transferable to a continuum based AAS instrumentation. ${ }^{42}$ Intermediate precision estimates using New York State's RM 028 (6.7 $\mu \mathrm{g} /$ dl) are $0.2 \mu \mathrm{g} / \mathrm{dl}$ by the continuum correction method and $0.1 \mu \mathrm{g} / \mathrm{dl}$ by Zeeman corrected AAS. ${ }^{41}$ At a detection limit of 0.75 for Zeeman AAS and 0.50 for continuum AAS, the precision is approximately 0.25 and $0.17 \mu \mathrm{g} / \mathrm{dl}$, similar to that reported at $6.7 \mu \mathrm{g} / \mathrm{dl}$.

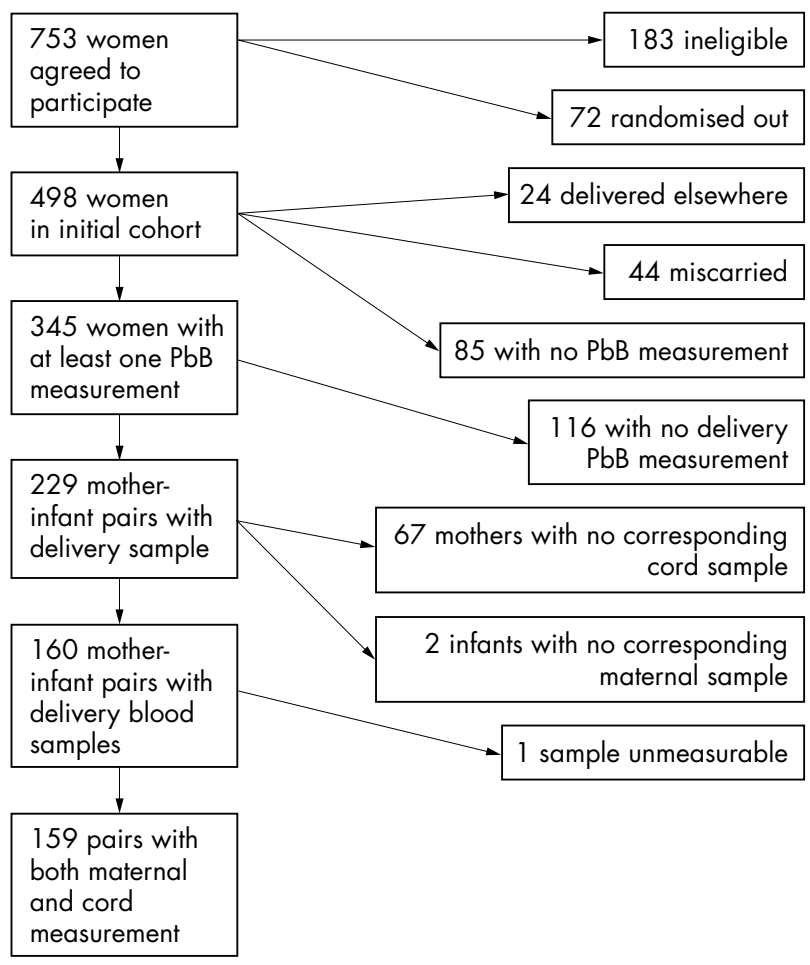

Figure 1 Creation of a cohort among Pittsburgh, PA women seeking prenatal care at Magee-Womens Hospital, 1992-95. PbB, blood lead.

\section{Policy implications}

- These findings give additional support to efforts to control blood pressure (particularly in those over 30 years of age), encourage iron supplementation when appropriate, and reduce alcohol consumption during pregnancy.

- Interventions to reduce prenatal exposure to lead can target not only overall maternal exposure, but also modifiable factors that influence transfer from the mother to the fetus.

Several comparisons were made to determine the acceptability of values measured years after blood collection. First, both laboratories participated satisfactorily in Clinical Laboratory Improvement Amendment (CLIA) approved proficiency testing programmes for blood lead using similar analytical methodologies. Twenty specimens were analysed by both laboratories, and of these, $80 \%$ were within $1 \mu \mathrm{g} / \mathrm{dl}$, with the remainder split between specimens that were higher in the concurrent analysis and those higher in the later determination. Second, we recently replicated our published analyses $^{40}$ of the maternal determinants of blood lead concentration $(\mathrm{PbB})$ and found that the regression models showed the same variables to be predictive regardless of whether the lead determinations were conducted concurrently or later. Third, the findings in the present examination of cord versus maternal blood lead were unchanged by inclusion or exclusion of the later assays. Therefore, we included them in the analyses presented.

Of the 159 pairs with information on both maternal and cord lead, $141 \mathrm{PbB}$ determinations were completed concurrently with specimen collection (1992-95) and 18 in 1998. In 106 cases, the maternal blood draw was performed during labour, and in 53 cases, after delivery. $\mathrm{PbB}$ was expressed in $\mu \mathrm{g}$ of lead per dl of whole blood.

\section{Data collection}

Trained staff interviewed the women face-to-face twice during their pregnancies, once shortly after enrolment (mean week of gestation: 14, range 8-18), and once late in the pregnancy (mean week: 36, range 31-41). Women were questioned about their medical, occupational, and lifestyle characteristics. Calcium intake was assessed through a modified Block food frequency questionnaire, ${ }^{43}$ which included the foods that account for most of the calcium consumed in the typical US diet, ${ }^{44}$ as well as questions on antacid, supplement, and vitamin use. Dietary calcium was calculated using the Block DIETSYS software version 3.0, ${ }^{45}$ and the Physician's Desk Reference provided estimates for calcium from antacids and supplements. ${ }^{46}$ Blood pressure was taken by study personnel according to the protocol of the ARIC (Atherosclerosis Risk in Communities) study ${ }^{47}$ Medical records were abstracted for details of medications used; prenatal, labour, and delivery histories; and information about the infant.

\section{Predictor variables}

Certain factors were considered as possible sources of variation in the difference between maternal and fetal $\mathrm{PbB}$, based on previous literature on humans and animals (table 1). Since blood flow and blood pressure have been linked to lead in humans and guinea pigs, ${ }^{48}$ we evaluated systolic and diastolic blood pressure and self-reported hypertension among the variables that we screened. Because the blood-bone lead equilibrium changes during 
pregnancy, calcium (which may affect the release of lead from bone $\left.{ }^{40}{ }^{49}\right)$, haemoglobin $(\mathrm{Hb})$, and sickle cell trait were examined. Reproductive history, medication use, and infection could also have effects on the structure or blood flow of the placenta. ${ }^{50}$ Because fetal stress has been associated with increased relative lead burden, ${ }^{51}$ we looked at factors such as birth weight and Apgar score. Finally, factors that might reflect the measurement and sample properties were examined, such as delayed versus concurrent lead analysis and time of maternal blood draw relative to delivery.

To represent variability in amount of lead transferred, the difference between cord and maternal whole $\mathrm{PbB}$ concentration, as well as a dichotomous indicator of whether the cord $\mathrm{PbB}$ was higher/not higher than maternal $\mathrm{PbB}$, were the outcomes for this study. The ratio of maternal to cord $\mathrm{PbB}$ was also examined.

\section{Statistical analysis}

To determine comparability across three groups of subjects, analysis of variance was performed. The three groups were: those without a cord PbB, those for whom $\mathrm{PbB}$ was measured a few years after data collection, and those with cord $\mathrm{PbB}$ determination performed concurrently with data collection.

Table 1 Factors found, in a bivariate screen, to be associated with cord blood lead relative to maternal blood lead in a cohort of 159 Pittsburgh, PA women, 1992-95

\begin{tabular}{lll} 
& Associated* & \\
\cline { 2 - 2 } & Difference† & Binary \\
\hline Demographic & & \\
Black race & neg & 0 \\
Highest income category & 0 & neg \\
Separated marital status & pos & pos \\
Educational disadvantage & 0 & neg \\
Lifestyle & & \\
Alcohol & pos & pos \\
Coffee/tea drinks per month & 0 & neg \\
Passive smoking & pos & 0 \\
Milk while adolescent & neg & 0 \\
Medical/obstetric & & \\
5 minute Apgar score & pos & 0 \\
Baby to intensive care unit & neg & 0 \\
Number of abortions & pos & 0 \\
Number of miscarriages & neg & 0 \\
Chlamydia & pos & 0 \\
Trichomonas & neg & 0 \\
Sexually transmitted disease & pos & 0 \\
Genitourinary infection & neg & neg \\
Cold medicines & neg & 0 \\
Augmented labour & neg & neg \\
Systolic blood pressure & pos & pos \\
Diastolic blood pressure & 0 & pos \\
Weight gain & pos & 0 \\
BMl & 0 & pos \\
Haemoglobin & neg & neg \\
Factors affecting blood lead measurement & & \\
Blood specimen measured later & pos & pos \\
\hline
\end{tabular}

*The following variables were not associated with either the difference or the ratio: age; calcium consumed during the pregnancy; calcium intake from milk; milk intake as a child; physical exertion at home or work; infant weight, length, or head circumference; parity; use of nausea medications; complications of labour and delivery; gestational age at birth; paternal exposure to lead; time between blood draw and birth. † Variables associated with difference between maternal and cord $\mathrm{PbB}$ at $p=0.20$ or showing a difference $>0.1$. pos indicates association with a higher lead level of cord blood, relative to maternal; neg indicates association with lower lead level of cord blood; 0 indicates no association.

\pm Variables associated with binary outcome at $p=0.20$ or $O R>2$. pos indicates increased odds of higher lead level of cord blood, relative to maternal; neg indicates association with lower lead level of cord blood; 0 indicates no association.
Initially, to reduce a large list of candidate predictors of potential maternal-fetal transfer, bivariate associations were examined for each variable and outcome; variables that were significant at $\alpha=0.20$ or OR greater than 2 were included in subsequent linear and logistic models. All variables that passed this initial bivariate screen were then included in multiple linear (for the difference) and logistic (for the dichotomous outcome) models, in which variables were eliminated that satisfied a criterion of $p>0.20$. In the next step, some variables that were not predictive of the outcome at $\alpha=0.20$ were reintroduced to examine as potential confounding: race, age, parity, and smoking. In most cases, inclusion of these variables did not change the effect estimates in the multivariable models, so they were not included in the final model. ${ }^{52}$ Finally, variables that were predictive of the cord-maternal $\mathrm{PbB}$ difference were entered in the logistic model, and vice versa. Interactions with age and weight gain were examined as well.

A number of sensitivity analyses were performed. Because the samples analysed later may have been compromised, we report models with and without those observations. The extent of the effect of missing data was assessed using multiple imputation with SAS's PROC MI and PROC MIANALYZE. Sickle cell trait, weight gain, and alcohol use later in pregnancy were each missing for some observations, and the imputation model contained those variables as well as race, age, pre-pregnancy body mass index (BMI), education, smoking status, alcohol use at other times, and the other variables in the prediction model. As additional sensitivity analyses, the models were fit using only the measurements that could be considered to be more robust: those maternal and cord samples with $\mathrm{PbB}$ above $1 \mu \mathrm{g} / \mathrm{dl}$ and the maternal specimens collected before delivery.

\section{RESULTS}

Mean maternal $\mathrm{PbB}$ at delivery was $1.93 \mu \mathrm{g} / \mathrm{dl}$, with a range of $0.55-4.70 \mu \mathrm{g} / \mathrm{dl}$; mean cord lead was $1.64 \mu \mathrm{g} / \mathrm{dl}$, with a range of $0.05-3.95 \mu \mathrm{g} / \mathrm{dl}$. The Pearson correlation coefficient between maternal and cord $\mathrm{PbB}$ was $r=0.79$. On average, cord $\mathrm{PbB}$ was lower than maternal PbB by $0.30 \mu \mathrm{g} / \mathrm{dl}(95 \% \mathrm{CI}$ -0.38 to $-0.21 \mu \mathrm{g} / \mathrm{dl}$ ), with a range of -1.93 to $1.20 ; 45$ of the pairs $(28 \%)$ had the cord blood value higher than the mother's PbB.

The women included in this analysis differed in some ways from those in the overall parent study: they were more likely to be white, nulliparous, and higher income than those lacking a cord measurement (table 2). Although the samples analysed for lead at a later time point were chosen randomly, the women differed in some respects from those for whom $\mathrm{PbB}$ was measured concurrently with data collection: they were more likely to be white and older, and their babies were of lower birth weight.

Bivariate analysis indicated a number of factors associated with maternal-fetal $\mathrm{PbB}$ difference (table 1), but in multivariate modelling, the strongest associations were seen with medical factors (table 3). Maternal $\mathrm{Hb}$ and sickle cell trait were associated with reduced fetal lead relative to maternal lead. Compared with the 25th centile of maternal $\mathrm{Hb}$, the 75 th centile was associated with $1.32 \mu \mathrm{g} / \mathrm{dl}$ lower cord relative to maternal blood lead. Children born to women with sickle cell trait had on average $0.8 \mu \mathrm{g} / \mathrm{dl}$ relatively lower lead. There was a significant interaction between age and blood pressure as well as weight gain and blood pressure: among mothers aged 30 years or over, or those who had gained more weight during pregnancy, a higher blood pressure was associated with a relatively greater lead concentration in the cord blood. The findings were unchanged when analysis was limited to the specimens analysed concurrently with data collection (table 3 ). 
Table 2 Characteristics of a cohort of Pittsburgh, PA pregnant women, 1992-95

\begin{tabular}{|c|c|c|c|c|}
\hline & $\begin{array}{l}\text { Both maternal and } \\
\text { cord blood } \\
\text { measurements, samples } \\
\text { analysed shortly after } \\
\text { delivery ( } n=140) \\
n(\%)\end{array}$ & $\begin{array}{l}\text { Both maternal and } \\
\text { cord blood } \\
\text { measurements, } \\
\text { samples analysed } \\
\text { later ( } \mathrm{n}=19) \\
\mathrm{n}(\%)\end{array}$ & $\begin{array}{l}\text { Maternal lead } \\
\text { measurement at } \\
\text { delivery, no cord } \\
\text { blood ( } \mathrm{n}=67) \\
\mathrm{n}(\%)\end{array}$ & $\mathbf{p}^{*}$ \\
\hline \multicolumn{5}{|l|}{ Race† } \\
\hline Black & $64(46)$ & $6(32)$ & $38(58)$ & \\
\hline White & 74 (54) & $13(68)$ & 27 (42) & 0.08 \\
\hline \multicolumn{5}{|l|}{ Age (y) } \\
\hline $18-20$ & $42(30)$ & $3(16)$ & $9(13)$ & \\
\hline $21-25$ & $53(38)$ & $9(47)$ & $32(48)$ & \\
\hline $26-30$ & $30(21)$ & $1(5)$ & 13 (19) & \\
\hline$>30$ & $15(11)$ & $6(32)$ & 13 (19) & 0.02 \\
\hline \multicolumn{5}{|l|}{ Parity } \\
\hline 0 & $62(44)$ & $9(47)$ & $19(28)$ & \\
\hline 1 & $46(33)$ & $4(21)$ & $22(33)$ & \\
\hline $2+$ & $32(23)$ & $6(32)$ & 26 (39) & 0.09 \\
\hline \multicolumn{5}{|l|}{ Annual income category } \\
\hline$<\$ 10000$ & $56(46)$ & $4(24)$ & $36(59)$ & \\
\hline$\$ 10-\$ 15000$ & $25(21)$ & $3(18)$ & $5(8.2)$ & \\
\hline$\$ 15-\$ 25000$ & $19(16)$ & $5(29)$ & $12(20)$ & \\
\hline$>\$ 25000$ & 21 (17) & $5(29)$ & $8(13)$ & 0.08 \\
\hline \multicolumn{5}{|l|}{ Smoking, interview 1 or 2} \\
\hline Non-smoker & $89(64)$ & $12(63)$ & $43(64)$ & \\
\hline Smoker & $51(36)$ & $7(37)$ & $24(36)$ & 1.00 \\
\hline \multicolumn{5}{|l|}{ Mean calcium intake } \\
\hline$>1200$ mg/day & $87(62)$ & $12(63)$ & $42(63)$ & \\
\hline$<1200 \mathrm{mg} /$ day & $53(38)$ & $7(37)$ & 25 (37) & 0.99 \\
\hline \multicolumn{5}{|l|}{ Treated for anaemia§ } \\
\hline Yes & $36(26)$ & $4(22)$ & $15(23)$ & 0.87 \\
\hline No & $104(74)$ & $14(78)$ & $51(77)$ & \\
\hline \multicolumn{4}{|l|}{ Mean maternal lead at } & 0.27 \\
\hline Mean cord blood lead (SD) & $1.65(0.76)$ & $1.57(0.79)$ & & 0.69 \\
\hline \multicolumn{5}{|l|}{ Mean birth weight in grams } \\
\hline Mean haemoglobin in & & & & \\
\hline $\begin{array}{l}\mathrm{g} / 100 \mathrm{ml}(\mathrm{SD}) \\
\text { Mean systolic blood }\end{array}$ & $12.1(0.84)$ & $12.2(0.67)$ & $12.0(0.77) \dagger$ & 0.69 \\
\hline $\begin{array}{l}\text { pressure throughout } \\
\text { pregnancy in } \mathrm{mmHg} \text { (SD) }\end{array}$ & $112(7.6)$ & $110(5.9)$ & $112(7.1)$ & 0.75 \\
\hline $\begin{array}{l}\text { *Two sided, } \chi^{2} \text { test for categ } \\
\text { †Four women missing or oth } \\
\ddagger \text { Missing data on } 27 \text { women } \\
\S \text { Missing data on } 2 \text { women. }\end{array}$ & $\begin{array}{l}\text { cal variables, ANOVA f } \\
\text { race. }\end{array}$ & continuous variables. & & \\
\hline
\end{tabular}

Similar factors were significant in the logistic model (table 4), although all the women with sickle cell trait $(n=5)$ had maternal lead higher than their infant, so this variable could not be included. The logistic model also showed increased odds of the cord $\mathrm{PbB}$ being higher than the maternal PbB for infants delivered by caesarean section. Both the blood pressure and caesarean section associations were attenuated when the samples analysed later were omitted.

A few non-medical variables were associated with the outcome. Alcohol consumption in the second and third trimesters was associated with an OR of 7.7 (95\% CI 2.4 to 24.4) for higher cord than maternal PbB; no association was seen for first trimester alcohol consumption. Children born in the winter had relatively higher cord $\mathrm{PbB}$ than maternal (season was not associated with the timing of lead determination).

Calcium intake and physical exertion were not associated with differences between maternal and cord $\mathrm{PbB}$ (table 1). Those with greater fetal $\mathrm{PbB}$ relative to maternal $\mathrm{PbB}$ did not differ with regard to race, parity, or smoking, nor did these variables confound any of the results.

Use of the ratio of maternal/cord $\mathrm{PbB}$ as an outcome measure yielded results similar to those of the difference between maternal and cord $\mathrm{PbB}$ (data not shown). Data were missing for $10(6 \%)$ of the observations on at least one of the following: sickle cell trait, weight gain, alcohol use. For models of the cord-maternal difference in $\mathrm{PbB}$, multiple imputation gave essentially identical beta estimates as models based on only the complete observations, except for $\mathrm{Hb}$, which increased from -1.18 to $-1.04 \mu \mathrm{g} / \mathrm{dl}$; standard errors and p values were similarly close. Restriction of the analysis to those measurements greater than $1 \mu \mathrm{g} / \mathrm{dl}$ changed the beta estimates only in the second decimal place. Restriction of the model to those samples taken before delivery strengthened the sickle cell and delivery in winter associations (for the difference, from -0.76 to -0.94 and from 0.12 to 0.26 , respectively; all other variables changed by less than 0.06).

\section{DISCUSSION}

This analysis looked at factors that might influence the dose of lead an infant receives, relative to maternal $\mathrm{PbB}$. The results suggest that alcohol use late in pregnancy, maternal $\mathrm{Hb}$ during pregnancy, and blood pressure may explain some of the variability in cord PbB beyond that explained by the mother's lead level.

Rothenberg's group has studied the same issue in a more highly lead exposed population than ours. ${ }^{37}{ }^{38}$ They found a decreased maternal/cord ratio associated with high blood pressure, caesarean delivery, parity, and increasing maternal 
Table 3 Results of multiple linear regression models predicting the difference between cord and maternal blood lead in a cohort of Pittsburgh, PA pregnant women, 1992-95

\begin{tabular}{|c|c|c|c|c|c|}
\hline & \multicolumn{2}{|c|}{ All samples $(n=159)$} & & \multicolumn{2}{|c|}{$\begin{array}{l}\text { All samples analysed shortly } \\
\text { after delivery }(n=131)\end{array}$} \\
\hline & $\beta$ & $95 \% \mathrm{Cl}$ & & $\boldsymbol{\beta}$ & $95 \% \mathrm{Cl}$ \\
\hline Sample analysed in second batch & 0.20 & -0.03 to 0.44 & & & \\
\hline Blood pressure, centred, per $10 \mathrm{~mm} \mathrm{Hg}$ & -0.06 & -0.20 to 0.08 & Blood pressure, centred, per $10 \mathrm{~mm} \mathrm{Hg}$ & -0.06 & -0.20 to 0.08 \\
\hline Mean $\mathrm{Hb}$, per $1 \mathrm{~g} / 100 \mathrm{ml}$ & -0.12 & -0.22 to -0.02 & Mean $\mathrm{Hb}$, per $1 \mathrm{~g} / 100 \mathrm{ml}$ & -0.12 & -0.22 to -0.02 \\
\hline Alcohol, 2nd interview, yes/no & 0.36 & 0.14 to 0.58 & Alcohol, 2nd interview, yes/no & 0.33 & 0.10 to 0.55 \\
\hline Sickle cell trait & -0.76 & -1.21 to -0.32 & Sickle cell trait & -0.74 & -1.17 to -0.30 \\
\hline Previous miscarriage & -0.20 & -0.39 to -0.01 & Previous miscarriage & -0.23 & -0.43 to -0.03 \\
\hline Delivery in winter & 0.12 & -0.05 to 0.29 & Delivery in winter & 0.10 & -0.08 to -0.28 \\
\hline Mother $>30$ y & -0.22 & -0.44 to 0.00 & Mother $>30$ y & -0.08 & -0.32 to 0.16 \\
\hline Weight gain $>40 \mathrm{lb}$ & 0.01 & -0.16 to 0.19 & Weight gain $>40 \mathrm{lb}$ & 0.02 & -0.17 to 0.20 \\
\hline Blood pressure $\times$ mother's age $>30$ & 0.36 & 0.09 to 0.62 & Blood pressure $\times$ mother's age $>30$ & 0.35 & 0.07 to 0.64 \\
\hline Blood pressure $\times$ weight gain & 0.26 & 0.04 to 0.47 & Blood pressure $\times$ weight gain & 0.28 & 0.05 to 0.50 \\
\hline
\end{tabular}

age, and increased maternal/cord ratio with daily milk drinking and previous premature birth (Rothenberg et al, personal communication). We also found a relatively higher fetal $\mathrm{PbB}$ with increased blood pressure (among women over 30 years and with increasing weight gain), even though women with underlying hypertension were excluded from our study. Although the mechanism for the effect of blood pressure is not clear, lead has been associated with blood pressure in adults in several studies. ${ }^{53}{ }^{54}$ Unlike previous studies, which have focused on lead as a predictor of cardiovascular health outcomes, in this study we were interested in the potential effects of blood pressure on lead levels as the outcome. Our results differ from those of Rothenberg et al with respect to caesarean section and parity. We saw no association with calcium intake, unlike Rothenberg and despite a previous article associating higher maternal $\mathrm{PbB}$ with lower calcium..$^{40}$ It is possible that the effects of these factors are only apparent at high levels of exposure, or the methods of analysis gave rise to divergent findings (the structure of the statistical models is different).

One of the strongest associations in our data was with alcohol consumption reported at the second (late pregnancy) interview: higher alcohol use was associated with a greater cord $\mathrm{PbB}$ relative to maternal $\mathrm{PbB}$. Alcohol has been shown to potentiate the effects of lead and to cause increased absorption by various organs in rats. ${ }^{55}$ Our results are consistent with the analyses of Ernhart and colleagues ${ }^{23}$ and Rabinowitz, ${ }^{22}$ but not with that of Rothenberg and colleagues. $^{38}$ We do not know if the levels of alcohol consumption differed in the Mexico City women as compared with our study cohort.

We also saw an association with $\mathrm{Hb}$, which may change the proportions of bound lead versus free plasma lead or correct for haemodilution. Similarly, sickle cell trait appears to reduce cord $\mathrm{PbB}$, perhaps due to a different affinity for lead of sickle red blood cells, as compared with normal red blood cells (RBCs). ${ }^{56} 57$

Strengths of our study include detailed measurement of a large number of covariates and prospective measurements. Sensitivity analyses indicated the results were robust. For instance, at low levels of lead small measurement errors could have a large impact, but restriction of the model to only those women with lead higher than $1 \mu \mathrm{g} / \mathrm{dl}$ did not change the conclusions. Likewise, blood loss at delivery, fluid replacement, and stress conditions could affect maternal and fetal PbB concentrations, but restriction to the maternal blood samples taken before delivery did not change the overall conclusions. With regard to haemodilution, we

Table 4 Models of dichotomous (cord higher/not higher than maternal)

\begin{tabular}{|c|c|c|c|c|}
\hline & $\beta$ & $95 \% \mathrm{Cl}$ & OR & $95 \% \mathrm{Cl}$ \\
\hline \multicolumn{5}{|l|}{ All samples $(n=157)$} \\
\hline Sample analysed in second batch & 1.63 & 0.35 to 2.91 & 5.11 & 1.42 to 18.33 \\
\hline Blood pressure, centred, per $10 \mathrm{~mm} \mathrm{Hg}$ & 0.40 & -0.19 to 0.99 & & \\
\hline Mean $\mathrm{Hb}$, per $\mathrm{g} / 100 \mathrm{ml}$ & -0.61 & -1.14 to -0.08 & 0.55 & 0.32 to 0.93 \\
\hline Alcohol, 2nd interview, yes/no & 2.04 & 0.88 to 3.19 & 7.67 & 2.41 to 24.38 \\
\hline Caesarean section & -1.25 & -3.04 to 0.55 & 0.29 & 0.05 to 1.73 \\
\hline Previous miscarriage & -0.82 & -2.08 to 0.43 & 0.44 & 0.13 to 1.54 \\
\hline Previous abortion & 0.78 & -0.21 to 1.77 & 2.18 & 0.81 to 5.89 \\
\hline Delivery in winter & 0.79 & -0.10 to 1.69 & 2.21 & 0.91 to 5.40 \\
\hline Mother $>30$ y & -2.09 & -4.10 to -0.08 & & \\
\hline Blood pressure $\times$ mother's age $>30$ & 4.02 & 0.75 to 7.29 & & \\
\hline \multicolumn{5}{|c|}{ All samples analysed shortly after delivery $(n=138)$} \\
\hline Blood pressure, centred, per $10 \mathrm{~mm} \mathrm{Hg}$ & 0.43 & -0.17 to 1.03 & & \\
\hline Mean $\mathrm{Hb}$, per $\mathrm{g} / 100 \mathrm{ml}$ & -0.58 & -1.12 to -0.04 & 0.56 & 0.33 to 0.96 \\
\hline Alcohol, 2nd interview, yes/no & 1.92 & 0.76 to 3.09 & 6.84 & 2.13 to 21.92 \\
\hline Caesarean section & -0.88 & -2.69 to 0.93 & 0.42 & 0.07 to 2.54 \\
\hline Previous miscarriage & -0.84 & -2.19 to 0.52 & 0.43 & 0.11 to 1.68 \\
\hline Previous abortion & 0.62 & -0.43 to 1.67 & 1.85 & 0.65 to 5.29 \\
\hline Delivery in winter & 0.66 & -0.30 to 1.61 & 1.93 & 0.74 to 5.01 \\
\hline Mother $>30$ y & -1.17 & -3.19 to 0.85 & & \\
\hline Blood pressure $\times$ mother's age $>30$ & 2.66 & -0.12 to 5.43 & & \\
\hline
\end{tabular}

Positive association increased odds of having cord $\mathrm{PbB}$ higher than maternal. 
controlled for $\mathrm{Hb}$, and also note that adjustment for weight gain as a continuous or categorical variable did not modify the other results. Some data were missing, but imputation showed they had little effect. The examination of a large number of variables could have created spurious chance associations, but the similarity of effects estimated in three forms (linear difference, logistic, and exponential model of the ratio [not shown]) as well as their confirmation in other studies, argue that this is not the case. The lead measurements were not all analysed at the same lab, and some $(40 / 451,9 \%)$ of the stored samples that were not analysed had small clots, leading us to suspect the validity of those measurements. However, the effect estimates were not confounded by timing or location of laboratory analysis. Thus, the consistency of findings throughout these sensitivity analyses strengthens confidence in the associations.

The study population was predominantly young, low income, and urban, and was balanced between white and African-American women; the exclusion of women who were not in prenatal care by week 13 may limit generalisability. Women who had both cord and maternal lead measurements at delivery were different from other women in the broader study; they were of lower parity, higher income, and their babies were of higher birth weight. It is difficult to determine whether these differences are important or not. Labour progresses more rapidly for women of higher parity and delivery is quicker for low birth weight infants, who also have more complications. Therefore, lack of a cord blood sample could simply be a marker for either a quick delivery or a complicated birth, when the nurses might not have had time to collect the specimen.

Lead transfer has a greater potential impact in more highly exposed populations; our cohort had a low mean level, as is currently common in the USA (mean lead for this study $\approx 2 \mu \mathrm{g} / \mathrm{dl}$, US mean for ages $20-49=2.1 \mu \mathrm{g} / \mathrm{dl}^{58}$ ). Despite the low concentrations, known risk factors for increased lead were easily identified, as we reported in previous work, ${ }^{40}$ indicating a high signal:noise ratio in the lead determinations. The consistency for many of our findings with other studies of more highly exposed populations provides reassurance that the associations are not artefacts. Also, the maternal-cord $\mathrm{PbB}$ association has been shown to be linear across a wide range of levels. ${ }^{16}$

Future studies should seek more refined methods of measuring placental transfer; differences between maternal and cord $\mathrm{PbB}$ are only partial measures of transfer. Any factor that caused changes in the maternal plasma-RBC-bone equilibrium or in excretion, resorption, or accumulation of lead in the fetus, or that affected placental transfer per se, could alter the difference between maternal and cord PbB. We had measurements in whole blood; plasma blood lead may be more predictive of cord blood lead. ${ }^{59}$ The $\delta$-aminolevulinic acid dehydratase (ALA-D) genotype may influence lead susceptibility, ${ }^{60}$ and ALA-D activity is higher in cord than maternal blood. ${ }^{61}$ Also, knowledge of both the total $\mathrm{Hb}$ and the percentage of fetal versus adult $\mathrm{Hb}$ in the cord blood would have been valuable, since fetal $\mathrm{Hb}$ has a higher affinity for lead than does adult $\mathrm{Hb}^{62}$ and its proportion of the total varies across newborns. Notably, sudden infant death syndrome has been linked both to lead, ${ }^{63}$ as well as the percent adult haemoglobin in the newborn. ${ }^{64}$

In conclusion, this analysis suggests that sickle cell trait, alcohol use, and maternal blood pressure and haemoglobin, among other factors, influence lead transfer to the fetus. If corroborated, these findings could give additional impetus to efforts to control blood pressure (particularly in those over 30 years of age), encourage iron supplementation when appropriate, and reduce alcohol consumption during pregnancy. While the best way to reduce prenatal transmission is to reduce maternal exposure to lead, future research should also focus on how we can mitigate lead's effects on development by reducing transfer to the infant.

\section{ACKNOWLEDGEMENTS}

This work was supported by grant R01-ES05738 from the National Institute of Environmental Health Sciences.

Emily Harville is a Howard Hughes Medical Institute Predoctoral Fellow.

\section{Authors' affiliations}

E W Harville, I Hertz-Picciotto, Department of Epidemiology, University of North Carolina-Chapel Hill, USA

K Chantala, Carolina Population Center, University of North CarolinaChapel Hill, USA

M Schramm, M Watt-Morse, Department of Obstetrics and Gynecology, Magee-Womens Hospital, USA

J Osterloh, Department of Laboratory Medicine, University of California at San Francisco, USA

P J Parsons, Wadsworth Center, New York State Department of Health, USA

W Rogan, Epidemiology Branch, National Institute of Environmental Health Sciences, USA

Competing interests: none declared

\section{REFERENCES}

1 Baghurst PA, McMichael AJ, Wigg NR, et al. Environmental exposure to lead and children's intelligence at the age of seven years. The Port Pirie Cohort Study. N Engl J Med 1992;327:1279-84.

2 Dietrich KN, Succop PA, Berger OG, et al. Lead exposure and the cognitive development of urban preschool children: the Cincinnati Lead Study cohort at age 4 years. Neurotoxicol Teratol 1991;13:203-11.

3 Huel G, Tubert $P$, Frery $N$, et al. Joint effect of gestational age and maternal lead exposure on psychomotor development of the child at six years. Neurotoxicology 1992;13:249-54.

4 Bellinger D, Leviton A, Sloman J. Antecedents and correlates of improved cognitive performance in children exposed in utero to low levels of lead. Environ Health Perspect 1990;89:5-11.

5 Bellinger DC, Needleman HL, Leviton A, et al. Early sensory-motor development and prenatal exposure to lead. Neurobehavioral Toxicol Teratol 1984;6:387-402

6 Shen XM, Yan CH, Guo D, et al. Low-level prenatal lead exposure and neurobehavioral development of children in the first year of life: a prospective study in Shanghai. Environ Res 1998;79: 1-8.

7 Wasserman GA, Liu X, Popovac D, et al. The Yugoslavia Prospective Lead Study: contributions of prenatal and postnatal lead exposure to early intelligence. Neurotoxicol Teratol 2000;22:811-18.

8 Gonzalez-Cossio T, Peterson KE, Sanin LH, et al. Decrease in birth weight in relation to maternal bone-lead burden. Pediatrics 1997; 100:856-62.

9 Rothenberg SJ, Schnaas L, Perroni E, et al. Pre- and postnatal lead effect on head circumference: a case for critical periods. Neurotoxicol Teratol 1999;21:1-11.

10 Ernhart CB. A critical review of low-level prenatal lead exposure in the human: 1. Effects on the fetus and newborn. Reprod Toxicol 1992;6:9-19.

11 Ernhart CB. A critical review of low-level prenatal lead exposure in the human: 2. Effects on the developing child. Reprod Toxicol 1992;6:21-40.

12 Gulson BL, Mahaffey KR, Jameson CW, et al. Impact of diet on lead in blood and urine in female adults and relevance to mobilization of lead from bone stores. Environ Health Perspect 1999;107:257-63.

13 Hernandez-Avila M, Smith D, Meneses F, et al. The influence of bone and blood lead on plasma lead levels in environmentally exposed adults. Environ Health Perspect 1998;106:473-7.

14 Bellinger D, Leviton A, Waternaux C, et al. Longitudinal analyses of prenatal and postnatal lead exposure and early cognitive development. N Engl J Med 1987;316:1037-43

15 Han S, Qiao X, Kemp FW, et al. Lead exposure at an early age substantially increases lead retention in the rat. Environ Health Perspect 1997; 105:412-17.

16 Graziano JH, Popovac D, Factor-Litvak P, et al. Determinants of elevated blood lead during pregnancy in a population surrounding a lead smelter in Kosovo, Yugoslavia. Environ Health Perspect 1990;89:95-100.

17 Carbone R, Laforgia N, Crollo E, et al. Maternal and neonatal lead exposure in southern Italy. Biol Neonate 1998;73:362-6.

18 Nashashibi N, Cardamakis E, Bolbos G, et al. Investigation of kinetic of lead during pregnancy and lactation. Gynecol Obstet Invest 1999;48:158-62.

19 Gardella C. Lead exposure in pregnancy: a review of the literature and argument for routine prenatal screening. Obstet Gynecol Surv 2001;56:231-8.

20 Kalcher K, Kern W, Pietsch R. Cadmium and lead in the smoke of a filter cigarette. Science of the Total Environment 1993;128:21-35.

21 Watanabe T, Kasahara M, Nakatsuka H, et al. Cadmium and lead contents of cigarettes produced in various areas of the world. Science of the Total Environment 1987;66:29-37. 
22 Rabinowitz $M$. Environmental, demographic, and medical factors related to cord blood lead levels. Biol Trace Elem Res 1984;6:57-64.

23 Ernhart CB, Wolf AW, Sokol RJ, et al. Fetal lead exposure: antenatal factors. Environ Res 1985;38:54-66.

24 Rabinowitz M, Bellinger D, Leviton A, et al. Pregnancy hypertension, blood pressure during labor, and blood lead levels. Hypertension 1987; 10:447-51.

25 Rothenberg SJ, Manalo M, Jiang J, et al. Blood lead level and blood pressure during pregnancy in South Central Los Angeles. Arch Environ Health 1999;54:382-9.

26 Rabinowitz MB, Needleman HL. Temporal trends in the lead concentrations of umbilical cord blood. Science 1982;216:1429-31.

27 Farias $\mathbf{P}$, Borja-Aburto $\mathrm{VH}$, Rios $\mathrm{C}$, et al. Blood lead levels in pregnant women of high and low socioeconomic status in Mexico City. Environ Health Perspect 1996; 104:1070-4.

28 Rothenberg SJ, Kondrashov V, Manalo M, et al. Seasonal variation in bone lead contribution to blood lead during pregnancy. Environ Res 2001;85:191-4.

29 Gershanik JJ, Brooks GG, Little JA. Blood lead values in pregnant women and their offspring. Am J Obstet Gynecol 1974;119:508-11.

30 Harris P, Holley MR. Lead levels in cord blood. Pediatrics 1972;49:606-8.

31 Goyer RA. Transplacental transport of lead. Environ Health Perspect 1990;89:101-5.

32 Li KM. Lead values in umbilical cord blood and maternal blood. J R Soc Health 1988; 108:59

33 Tsuchiya H, Mitani K, Kodama K, et al. Placental transfer of heavy metals in normal pregnant Japanese women. Arch Environ Health 1984;39:11-17.

34 Zetterlund B, Winberg J, Lundgren G, et al. Lead in umbilical cord blood correlated with the blood lead of the mother in areas with low, medium or high atmospheric pollution. Acta Paediatr 1977;66:169-75.

35 Milman N, Christensen JM, Ibsen KK. Blood lead and erythrocyte zinc protoporphyrin in mothers and newborn infants. Eur J Pediatr 1988;147:71-3.

36 al-Saleh I, Khalil MA, Taylor A. Lead, erythrocyte protoporphyrin, and hematological parameters in normal maternal and umbilical cord blood from subjects of the Riyadh region, Saudi Arabia. Arch Environ Health 1995;50:66-73.

37 Rothenberg S, Schnaas L, Cansino-Ortiz S, et al. Neurobehavioral deficits after low level lead exposure in neonates: the Mexico City pilot study. Neurotoxicol Teratol 1989;11:85-93.

38 Rothenberg SJ, Karchmer S, Schnaas L, et al. Maternal influences on cord blood lead levels. J Expo Anal Environ Epidemiol 1996;6:21 1-27.

39 Sikorski R, Paszkowski T, Milart $\mathrm{P}$, et al. Intrapartum levels of trace metals in maternal blood in relation to umbilical cord blood values: lead, iron, copper, zinc. Int J Gynaecol Obstet 1988;26:213-21.

40 Hertz-Picciotto I, Schramm M, Watt-Morse M, et al. Patterns and determinants of blood lead during pregnancy. Am J Epidemiol 2000;152:829-37.

41 Parsons $\mathbf{P}$, Slavin W. A rapid Zeeman graphite furnace atomic absorption spectrometric method for the determination of lead in blood. Spectrochimica Acta B 1993;48B:925-39.

42 Qiao H, Parsons P, Slavin W. Transferability of a simple method for blood lead determination using furnace AAS and continuum background correction. Clin Chem 1995;41:1451-4.

43 Block G, Hartman AM, Naughton D. A reduced dietary questionnaire: development and validation. Epidemiology 1990;1:58-64.
44 Cummings S, Block G, McHenry K, et al. Evaluation of two food frequency methods of measuring dietary calcium intake. Am J Epidemiol 1987; 126:796-802.

45 Block G, Hartman A, Dresser C. A data-based approach to diet questionnaire design and testing. Am J Epidemiol 1986;124:453-69.

46 Anon. Fetal lead toxicity. Environ Health Perspect 1993;101:474-5.

47 National Heart Lung and Blood Institute. Manual 11. Sitting blood pressure and postural changes in blood pressure and heart rate. Collaborative Studies Coordinating Center. http://www.cscc.unc.edu/aric/visit/Sitting Blood Pressure_and_Postural_Changes_in_Blood_Pressure_and_Heart_Rate.2_11 . pdf (accessed 11 September 2002).

48 Kelman BJ, Walter BK. Transplacental movements of inorganic lead from mother to fetus. Exp Biol Med 1980;163:278-82.

49 Han S, Pfizenmaier DH, Garcia E, et al. Effects of lead exposure before pregnancy and dietary calcium during pregnancy on fetal development and lead accumulation. Environ Health Perspect 2000;108:527-31.

50 Stallmach T, Hebisch G. Placental pathology: its impact on explaining prenatal and perinatal death. Virchows Archive 2004;445:9-16.

51 Ernhart CB, Wolf AW, Kennard MJ, et al. Intrauterine exposure to low levels of lead: the status of the neonate. Arch Environ Health 1986;41:287-91.

52 Greenland S. Modeling and variable selection in epidemiologic analysis. Am J Public Health 1989;79:340-9.

53 Hertz-Picciotto I, Croff J. Review of the relation between blood lead and blood pressure. Epidemiol Rev 1993; 15:352-73.

54 Rothenberg SJ, Kondrashov V, Manalo M, et al. Increases in hypertension and blood pressure during pregnancy with increased bone lead levels. Am J Epidemiol 2002;156:1079-87.

55 Gupta V, Gill KD. Influence of ethanol on lead distribution and biochemical changes in rats exposed to lead. Alcohol 2000;20:9-17.

56 Suarez CR, Black LE 3rd, Hurley RM. levated lead levels in a patient with sickle cell disease and inappropriate secretion of antidiuretic hormone. Pediatr Emerg Care 1992:8:88-90.

57 Adams JG 3rd, Newman MV, Steinberg MH, et al. Effect of lead and ethanol upon gamma-globin synthesis in sickle reticulocytes. Am J Med Sci 1986;292:299-305

58 Anon. Update: blood lead levels-United States, 1991-1994. Morb Mortal Wkly Rep 1997:46:141-6.

59 Chuang HY, Schwartz J, Gonzales-Cossio T, et al. Interrelations of lead levels in bone, venous blood, and umbilical cord blood with exogenous lead exposure through maternal plasma lead in peripartum women. Environ Health Perspect 2001; 109:527-32.

60 Todd AC, Wetmur JG, Moline JM, et al. Unraveling the chronic toxicity of lead: an essential priority for environmental health. Environ Health Perspect 1996;104:141-6.

61 Campagna D, Huel G, Girard F, et al. Environmental lead exposure and activity of delta-aminolevulinic acid dehydratase (ALA-D) in maternal and cord blood. Toxicology 1999;134:143-52.

62 Ong CN, Lee WR. High affinity of lead for fetal haemoglobin. Br J Ind Med 1980;37:292-8.

63 Drasch GA, Kretschmer E, Lochner C. Lead and sudden infant death. Investigations on blood samples of SID babies. Eur J Pediatr 1988; 147:79-84.

64 Richardson DB, Wing S, Lorey F, et al. Adult hemoglobin levels at birth and risk of sudden infant death syndrome. Arch Pediatr Adolesc Med 2004;158:366-71 